\title{
THE RELATION BETWEEN THE CYCLE OF ADMINISTRATION OF CHEMOTHERAPY TO PSYCHOSOCIAL PROBLEMS IN BREAST CANCER PATIENTS
}

\author{
Sri Handayani ${ }^{1}$, Ulfah Nuraini Karim ${ }^{2}$, Puji Astuti Wiratmo ${ }^{3^{*}}$ \\ 1. RSUD KOJA, Jakarta-Indonesia \\ 2. Faculty of Nursing and Midwifery, Binawan University, Jakarta-Indonesia \\ 3. Faculty of Nursing and Midwifery, Binawan University, Jakarta-Indonesia
}

*Correspondence: Puji Astuti Wiratmo | Universitas Binawan | puji@ binawan.ac.id

\begin{abstract}
Introduction: Breast cancer is the most common malignant neoplasm that affects women. One of the treatments for breast cancer is chemotherapy which is carried out according to a particular schedule with a specified length of therapy to increase the patient's recovery rate. In addition to the physiological effects, chemotherapy also has a psychological impact on the patient. Fulfillment of psychosocial needs is important to improve the quality of life of patients caused by changes in physical, social, cognitive, spiritual, emotional and role functions. The purpose of this study was to determine the relationship between the cycle of chemoteraphy with psychosocial problems in breast cancer patients.

Method: This study is a quantitative correlational study using 54 breast cancer patients as samples by purposive sampling. Data collection was carried out during April 2020 to June 2020 in the chemotherapy room at Koja Hospital, North Jakarta. The Depression Anxiety Stress Scale (DASS 21) questionnaire was used to identify psychosocial problems in breast cancer patients. Statistical analysis of the Spearman rank test was carried out to analyze the relationship between chemotherapy cycles and psychosocial problems.

Results: The results showed that there was a relationship between chemotherapy cycles and psychosocial problems ( $\mathrm{p}$ value 0.001 ) although it showed a weak relationship between those two variables ( $\mathrm{r} 0.257$ ). Psychosocial problems identified included anxiety (53\%), depression (9.3\%), low self-esteem (16.7\%) and stress (20.4\%).

Conclusion: Nurses need to provide comprehensive nursing care for patients undergoing chemotherapy including identifying problems related to physical complaints and psychosocial needs so that nursing interventions can be given comprehensively to breast cancer patients undergoing chemotherapy.
\end{abstract}

Keywords: Nursing care, Breast cancer, Chemotherapy, Psychosocial problems

Received November 8, 2021; Accepted December 30, 2021

\section{INTRODUCTION}

Breast cancer is a malignant neoplasm where abnormal tissue growth occurs in the breast area, it grows infiltrates and undergoes metastasis (Kowalak JP, 2011). The Indonesian Ministry of Health (2019) states that the prevalence of cancer has increased in the last 5 years and the incidence of cancer in Indonesia is 136.2 per 100,000 population and this figure places Indonesia in 8th place with the most cases in Asia and 23rd in Southeast Asia. Breast cancer is the most common cancer in women. According to the Indonesian Ministry of Health (2019), breast cancer is the first highest case of female cancer, account for 42.1 per 100,000 population with an average death rate of 17 per 100,000 population.

One of the therapies given to breast cancer patients is chemotherapy. Chemotherapy in breast cancer patients is usually given in 6 cycles. Chemotherapy can cause both physiological and psychological effects. Physiological impacts that can occur are fatigue, lethargy, hair loss, intestinal and oral disorders, nausea and vomiting, oral mucositis, spinal cord disorders, infertility, menstrual \& menopausal disorders and disorders of other organs (Sitepu and Wahyuni, 2018). In addition to physiological impact, chemotherapy can also have psychological impact, including impaired self-esteem, sexuality, and anxiety (Smeltzer, 2010). The side effects of each cycle of chemotherapy in breast cancer patients are vary depending on the patient's body condition and also the coping of each individual which can cause psychosocial problems for oneself, family and society (Damayanti, 2018).

Psychosocial is a term that describes the relationship between a person's social condition and mental/emotional health. Psychosocial needs are needs that involve both psychological and social aspects 
that combine clinical psychological and social services and are related to mental conditions (Turner, 2011). The fulfillment of psychosocial needs is important because it has large impact on the quality of life of cancer patients and because it is related to changes in physical, social, cognitive, spiritual, emotional and role functions. In addition, physical symptoms such as pain, sleep disturbances and digestive disorders will greatly affect psychosocial needs (Utami and Mustikasari, 2019). Therefore, as a nurse in providing services to cancer patients, it is not only focused on physical complaints, but also must be holistic or comprehensive in all aspects of patient needs (Lewis, 2013).

Sitepu and Wahyuni (2017) have conducted research aimed for identifying the description of stress, anxiety and depression levels of breast cancer patients undergoing chemotherapy at HAM Hospital. The instrument used in this study was DASS 42 which has been modified consisting of 42 statements and had been validated and declared valid with a content validity index (CVI) value of 0.67 and a Cronbach alpha reliability test of 0.94 . The results showed that breast cancer patients undergoing chemotherapy experienced stress as much as $28.8 \%$, anxiety as much as $41.5 \%$, and depression as much as $19.5 \%$. Putri (2018) conducted a research aimed to identify the relationship between body image and sexual function of women with breast cancer. The study was conducted on 35 samples living at the Indonesian Cancer Foundation using BIS (Body Image Scale) and FSFI (Female Sexual Function Index) measuring instruments. The results showed that most of the respondents (89\%) had negative body image and most of the respondents (91\%) had poor sexual function. The results of the Spearman Rank statistical test showed a strong positive relationship between body image and sexual function of women with breast cancer ( $\mathrm{p} 0.001$ and $\mathrm{r}+0.852$ ).

A number of studies have been conducted in identifying psychosocial problems in patients with breast cancer, but there are still few studies that focus on psychosocial nursing problems in breast cancer patients, especially related to the impact of chemotherapy cycles. Based on a preliminary study conducted at the Koja Hospital, obtained from observations and interviews with 10 breast cancer patients who were undergoing chemotherapy, data obtained that 5 out of 10 patients were able to accept the disease, experienced worrying, anxiety and fear. In addition, they faced the threat of death and pain when undergoing therapy. This study aims to determine the relationship between the cycle of chemotherapy administration to psychosocial problems in breast cancer patients at Koja Hospital, North Jakarta.

\section{METHOD}

This study used a descriptive correlative design with a cross sectional approach. The target population in this study included all breast cancer patients undergoing chemotherapy at KOJA Hospital. The sample in this study was taken by purposive sampling and calculated using the Slovin sample size formula so that as many as 54 respondents were recruited in this study. The inclusion criteria in this study were: 1) Breast cancer patients undergoing chemotherapy at Koja Hospital, 2) Patients undergoing chemotherapy that had been carried out for more than one cycle, 3) Patients who could communicate well and 4) Patients who were willing to become respondents. The sample exclusion criteria in this study include: 1) Breast cancer patients who experienced psychological disorders, 2) Breast cancer patients with weak conditions and 3) Breast cancer patients who were not routinely undergoing chemotherapy. Before taking the data, the researcher explained about the purpose and benefits of the research to the respondents and asked the patients to sign the informed consent form if they were willing to become research respondents. Research data collection was carried out on breast cancer patients in the chemotherapy room on the 1st floor of Building B Koja Hospital, North Jakarta from April to June 2020. Researchers used the Depression Anxiety Stress Scale (DASS 21) instrument which is a standard instrument for measuring psychosocial problems in breast cancer patients. After the researcher explained the aims and objectives of the study and obtained the respondent's approval, the respondent filled out the DASS 21 questionnaire accompanied by the researcher. The results of data collection were then processed statistically including univariate analysis on demographic variables and psychosocial problem variables and bivariate analysis to analyze the relation between chemotherapy cycles and psychosocial problems.

\section{RESULTS}

Table 1. Distribution of Participants 


\begin{tabular}{l|c|c}
\hline \multicolumn{1}{c}{ Variable } & Total & Percentage \\
N & \\
\hline Age & 1 & $1,9 \%$ \\
Teenager & 20 & $37 \%$ \\
Early adulthood & 32 & $59,3 \%$ \\
Late adult & 1 & $1,9 \%$ \\
Elderly & & \\
\hline Marital Status & 44 & $81,5 \%$ \\
Married & 10 & $18,5 \%$ \\
Not married yet & 0 & 0 \\
Widow & & \\
\hline Number of children & 49 & $90,7 \%$ \\
Already have children & 5 & $9,3 \%$ \\
Have no children & & \\
\hline Cancer stage & 46 & $85,2 \%$ \\
Stage 3 Ca breast & 8 & $14,8 \%$ \\
Stage 2 Ca breast & & \\
\hline Chemotherapy cycle & 46 & $85,2 \%$ \\
Chemotherapy I & 8 & $14,7 \%$ \\
Chemotherapy II & & $53,7 \%$ \\
\hline Psychosocial problems & 29 & $9,3 \%$ \\
Anxiety & 5 & $16,7 \%$ \\
Stress & 9 & $20,4 \%$ \\
Low self esteem & 11 & \\
Depression & & \\
\hline
\end{tabular}

Table 1 shows univariate analysis where in the age variable, almost all respondents were in the adult age range, $59.3 \%$ of respondents were late adults and $37 \%$ were early adults. Only $1.9 \%$ of respondents were teenagers. In the marital status variable, most of the respondents (81.55) were married and only $18.5 \%$ of the respondents were unmarried. Meanwhile, most of the respondents had children $(90.7 \%)$ and only $9.3 \%$ of patients did not have children. In the type of breast cancer stage, most of the respondents in this study were at stage $3(85.2 \%)$ and the rest $(14.8 \%)$ were at stage 2. Meanwhile, based on chemotherapy cycle, $85.2 \%$ were undergoing chemotherapy cycle 1 and $14.7 \%$ undergoing chemotherapy cycle 2 . Based on the identification of psychosocial problems, breast cancer patients experienced anxiety as much as $53.7 \%$, stress as much as $20.4 \%$, low self-esteem as much as $16.7 \%$ and depression as much as $9.3 \%$.

Table 2: Analysis of the Relationship between Chemotherapy Cycles and Psychosocial Problems

\begin{tabular}{|c|c|c|c|c|c|c|c|c|c|c|c|c|}
\hline \multirow{3}{*}{$\begin{array}{c}\text { Chemoterapy } \\
\text { Cycle }\end{array}$} & \multicolumn{8}{|c|}{ Psychosocial Problems } & \multirow{2}{*}{\multicolumn{2}{|c|}{ Total }} & \multirow{3}{*}{ P-value } & \multirow{3}{*}{$\boldsymbol{r}$} \\
\hline & \multicolumn{2}{|c|}{ Anxiety } & \multicolumn{2}{|c|}{ Depression } & \multicolumn{2}{|c|}{ Low Self Esteem } & \multicolumn{2}{|c|}{ Stress } & & & & \\
\hline & $\mathrm{N}$ & $\%$ & $\mathrm{~N}$ & $\%$ & $\mathrm{~N}$ & $\%$ & $\mathrm{~N}$ & $\%$ & $\mathrm{~N}$ & $\%$ & & \\
\hline Chemoteraphy I & 27 & 58,7 & 3 & 6,5 & 9 & 19,6 & 7 & 15,2 & 46 & $100 \%$ & & \\
\hline Chemoterapy II & 2 & 25 & 2 & 25 & 0 & 0 & 4 & 50 & 8 & $100 \%$ & 0,00 & 0,257 \\
\hline Total & 29 & 53,7 & 5 & 9,3 & 9 & 16,7 & 11 & 20,4 & 54 & $100 \%$ & & \\
\hline
\end{tabular}

Table 2 is a bivariate analysis of the relationship between chemotherapy cycle and psychosocial problems and it can be seen that respondents who were in the first cycle of chemotherapy experienced anxiety (58.7\%), while the respondents who were in the second cycle of chemotherapy had stress of 50\%. Based on the results of the cross-test, a p-value of 0.001 was obtained, which indicated that there was a relationship between chemotherapy cycles and psychosocial problems. However, on the strength of the relationship, the correlation value was 0.257 , which means that the relationship between chemotherapy cycles and psychosocial problems shows a weak relationship.

\section{DISCUSSION}

Based on the age characteristics of breast cancer, it was found that almost all of the respondents were in the adult age range which is the reproductive age. This shows that age is a risk factor for breast cancer in women, where age over 35 years has a higher risk of breast cancer (Firasi and Yudhanto, 2016). It is 
possible for women over 35 years of age to still experience menstruation even though they do not ovulate. The reported parity factor has an influence on the incidence of breast cancer where nulliparous women have a 30\% risk of developing breast cancer compared to multiparous women. However, this is also influenced by the level of experience, where breastfeeding women have low estrogen and progesterone so that it affects the development of breast tissue proliferation (Anggraini and Ekawati 2016)

Some research results show that breast cancer patients experience psychosocial problems such as anxiety, depression and stress. Based on the results of the study, it was found that $53.7 \%$ of respondents experienced anxiety, $20.4 \%$ of stress, $16.7 \%$ of low self-esteem and $9.3 \%$ of depression. According to Misgiyanto and Susilawati (2014) anxiety is not only influenced by family support, but is influenced by internal factors such as age, sufferer experience, self-concept and role, socioeconomic level, type of action and therapeutic communication. While extrinsic factors are medical conditions, education level, information access and adaptation process. Educational factors affect the patient's level of anxiety but the factors of age, stage, occupation, and income do not affect the incidence of psychosocial problems in breast cancer patients (Utami and Mustikasari 2017). Nurses need to pay attention to the patient's psychosocial needs because the patient's psychological response to the disease conditions are stressor to increase the growth of cancer cells (Lali, et al 2018).

Based on the results of research conducted by Wahyuni (2015), it was found that the frequency of chemotherapy with the patient's quality of life had a significant relationship and indicated a strong correlation in a positive direction. Hilli, et al (2017) have also conducted research on 68 patients undergoing chemotherapy at the Prof.Dr.W.Z.Johannes Hospital Kupang and stated that the administration of chemotherapy drugs at a certain frequency had an impact on changes in the functional status of respondents caused by side effects of chemotherapy. Likewise, research conducted by Setiawan et al (2018) on 68 breast cancer patients who underwent chemotherapy in the Edelweis room of Ulin Hospital Banjarmasin showed that there was a relationship between the length of chemotherapy and the patient's self-concept.

Based on the theory, chemotherapy must be given through several cycles up to 6 cycles until the treatment period is complete in accordance with the chemotherapy treatment protocol (Tjokronegoro, 2006). The mechanism of action of chemotherapy drugs is to inhibit the division phase of cancer cells, but cells exposed to chemotherapy drugs may not experience cell death, thus chemotherapy doses need to be given repeatedly through several cycles in order to suppress the growth of cancer cells (Sudoyo, 2009). However, the increasing frequency of chemotherapy given to patients not only causes damage to cancer cells but also healthy cells. Damage to healthy cells will have an impact on body function and resistance which will also experience a decline and will have an impact on decreasing the patient's physical, psychological and social status (Lewis, 2013).

Changes in physical conditions caused by the disease and the process of treatment, result in psychological problems in breast cancer patients such as anxious, afraid, sad, angry, afraid to move and even withdraw from the environment. This will influence the individual in dealing with other people. Psychosocial problems will increase when individuals imagine changes in their future live due to illness or as a result of the process of handling a disease and experience a lack of information about the nature of a disease and its handling (Sitepu and Wahyuni, 2018). Subekti's research (2020) stated that the majority of cancer patients experience physical and psychological changes where these changes make them anxious and uneasy and the form of emotional response that generally appears when individuals diagnosed with cancer is rejection. At that time the individual tries to adapt to the disease whereby the goal is to reduce anxiety. Hospitalization is also one of the factors that can cause psychosocial problems. Cancerous patient who undergo treatment in hospital for surgery, chemotherapy, radiotherapy, or other treatment measures, also often experience anxiety. In addition, unprofessional attitude from doctors, nurses, or other hospital staff may cause the patient feel as they are merely the objects of examination. This condition causes patients often feel that they lose their identity and lose control over their bodies, making them feel uncomfortable undergoing treatment at the hospital so as to anxiety arises in the patient (Misgiyanto \& Susilawati, 2014). Anxiety is a part of psychological human response to a certain condition. Excessive anxiety in chemotherapy patients can also affect the patient's motivation in carrying out chemotherapy, thus affecting the chemotherapy program (Situmorang, 2019). 


\section{CONCLUSION}

Based on the results of research conducted on 54 breast cancer patients at Koja Hospital, North Jakarta, it was found that there was a relationship between the cycle of chemotherapy administration and psychosocial problems ( $\mathrm{p}$ 0.001). Giving chemotherapy to breast cancer patients can have physical and psychosocial impacts. Psychosocial impacts include anxiety, stress, low self-esteem and depression. The physical symptoms of breast cancer can affect the fulfillment of psychosocial needs that require a special nursing format for psychosocial needs. Nurses as health professionals who are always close to patients need to provide psychosocial support to patients and families, be able to identify coping and strengths possessed by patients and families, provide information and communicate therapeutically to patients and families so that the patient's physical and psychosocial needs can be met. In addition, support is needed so that patients will feel more calm and comfortable in undergoing the treatment process. Family support is one of the important elements in supporting their care process and reducing the anxiety they feel during the treatment process. Further research can be conducted based on the data from the results of this study on the effectiveness of providing nursing interventions in overcoming psychosocial problems in breast cancer patients

\section{REFERENCE}

Damayanti,N.A. (2010). Hubungan Keluarga Terhadap Tingkat Stress Pada Pasien Kanker Colon Yang Menjalani Kemoterapi Di Ruang Cendrawasih RSUP Dr Kardi Semarang. Undergraduate thesis, Universitas Muhammadiyah Semarang.

Ekawati \& Anggraini.T.Y.( 2016). Faktor Resiko Diit Pada Penderita Kanker Payudara. Jurnal Kesehatan Madani Medika. 7(1).

Firasi, A.A. \& Yudhanto, E. (2016). Hubungan Usia Terhadap Derajat Differensiasi Kanker Payudara Pada Wanita. Jurnal Kedokteran Diponegoro. 5(4).

Hilli, Y.W., Tat, F., \& Lektor, Y.M.K. (2017). Hubungan Karakteristik dan Frekuensi Kemoterapi Dengan Tingkat Gangguan Fisik (Alopesia, Nausea, dan Vomit) Pada Pasien Kanker Yang Menjalani Kemoterapi Di Ruangan Mutis RSUD Prof.Dr.W.Z Johannes Kupang. CHMK Nuising Scientific Journal. 1(2).

Kemenkes RI .(2019). Penyakit Kanker di Indonesia Berada Pada Urutan 8 di Asia Tenggara dan Urutan 23 di Asia. Direktorat Jenderal Pencegahan dan Pengendalian Penyakit. Kementrian Kesehatan Republik Indonesia. Tersedia pada http://p2p.kemkes.go.id/penyakit-kanker-di-indonesia-berada-pada-urutan-8di-asia-tenggara-dan-urutan-23-di-asia/. Diakses pada Juni 2020.

Kowalak JP, W. W. (2011). Buku Ajar Patofisiologi. Jakarta : EGC.

Lali, M.G., Wawo, A.M., \& Gerontini, R. (2018). Studi Fenomenologi : Eksplorasi Kebutuhan Psikososial Pasien Ca Mamae di RSUD Prof.Dr.W.Z Johannes Kupang. CHMK Nursing Scientific Journal. 2(2).

Lewis, S. L. (2013). Medical Surgical Nursing : Assessment Management and Clinical Problem. Elsevier Mosby.

Misgiyanto \& Susilawati.D. (2014). Hubungan Antara Dukungan Keluarga Dengan Tingkat Kecemasan Penderita Kanker Serviks Paliatif. Jurnal Keperawatan. 5(1). DOI: https://doi.org/10.22219/jk.v5i1.1855

Putri, C.H., Widjayanti,Y., \& Kurnyawaty,Y. (2018). Citra Tubuh Dan Fungsi Sksual Wanita Penderita kanker Payudara Di Yayasan Kanker Indonesia. Jurnal Penelitian kesehatan. 5 (2).

Setiawan.M., Lestari, D.R., \& Rachmawati,K. (2018). Hubungan Lama Keoterapi Dengan Konsep Diri Pasien Kanker Payudara Yang Menjalani Kemoterapi di RSUD Ulin Banjarmasin. Dinamika Kesehatan. 9(2).

Sitepu, Y.E. \& Wahyuni, S.E. (2018). Gambaran Tingkat Stress, Ansietas dan Depresi Pada Pasien Kanker Payudara Yang Menjalani Kemoterapi di RSUP H. Adam Malik Medan. Tropical Medicine. 1(1). DOI: $10.32734 /$ tm.v1i1.50

Situmorang, P.R. (2019) Hubungan Dukungan Sosial Keluarga Dengan Tingkat Kecemasan Pasien Penyakit Ca Servik Yang Menjalani Kemotherapi di Rumah Sakit Umum Imelda Pekerja Medan. Indonesian Trust Health Journal. 2(2). DOI: https://doi.org/10.37104/ithj.v2i2

Smeltzer, C. S. (2010). Buku Ajar Keperawatan Medikal Bedah Brunner \& Suddart. Jakarta: EGC.

Sudoyo, A. W. (2009). Buku Ajar Penyakit Dalam. Jilid II, Edisi V. Jakarta: InternaPublising 
Surbakti, E. (2013). Hubungan Riwayat Keturunan Dengan Terjadinya Kanker Payu- dara Pada Ibu Di RSUP H . Adam Malik Medan.Jurnal Precure. 1(1).

Tjokronegoro, A. (2006). Buku Ajar Ilmu Keperawatan.Jilid kedua. Jakarta: FKUI.

Turner, L. H. (2011). Pengantar Teori Komunikasi: Analisis dan Aplikasi. Jakarta: Salemba Humanika.

Utami,S.S. \& Mustikasari (2017). Aspek Psikososial Pada Penderita Kanker Payudara : Studi Pendahuluan. Jurnal Keperawatan Indonesia.20 (2). DOI: 10.7454/jki.v20i2.503

Wahyuni, T. (2015). Hubungan Antara Frekuensi Kemoterapi dengan Kualitas Hidup Perempuan dengan kanker payudara Yang Menjalani Kemoterapi di Ruang Kemoterapi RSUD PARIKASIT TENGGARONG. Jurnal Ilmu Kesehatan. 3(2). 